EKSAKTA Vol. 12 No. 1, 1-5

\title{
Penentuan Efisiensi Immobilisasi Kromium (VI) Pada Geopolimer Abu Sekam Padi Dengan Uji TCLP (Toxicity Characteristic Leaching Procedure)
}

\author{
Kun Sri Budiasih \\ Jurusan Pendidkan Kimia, FMIPA Universitas Negeri Yogayakarta \\ ks_budiasih@yahoo.co.uk
}

\begin{abstract}
This research aimed to determine the efficiency of immobilization of $\mathrm{Cr}(\mathrm{VI})$ on the rice husk ash based geopolymer with a TCLP (Toxicity Characteristic Leaching Procedure) study. The TCLP was refer to the standard method from Japan Environmental Agency. There were three variables used i.e., concentration of $\mathrm{Cr}(\mathrm{VI})$ impregnated, particles size, and the kind of leaching water. Determination of immobilization efficiency was done by calculate the concentration of $\mathrm{Cr}(\mathrm{VI})$ in the leachate water after the leaching processes. Quantitative measurement of the chromium was done by $\mathrm{Uv}-\mathrm{Vis}$ spectrometer with biphenyl carbazid reagent. Immobilization of $\mathrm{Cr}(\mathrm{VI})$ on the rice husk ash based geopolymer was establish until $25 \mathrm{ppm} \mathrm{Cr}$ impregnated. The efficiency of the immobilization can reach $90 \%$ - almost $100 \%$ depend on the variable of leaching processes.
\end{abstract}

Keywords: eficiency, immobilization, geopolimer, rice husk ash, TCLP study 